\title{
Genetic and morphometric differentiation in Old World bisexual species of Artemia (the brine shrimp)
}

\author{
ERNANI J. S. PILLA* \& JOHN A. BEARDMORE \\ School of Biological Sciences, University of Wales, Swansea, Swansea SA2 8PP, U.K.
}

\begin{abstract}
We studied bisexual populations of Eastern Old World (EOW) brine shrimp (Artemia) from China (A. sinica and Artemia sp.), Kazakhstan (Artemia sp.) and Iran (A. urmiana), together with one population of Western Old World (WOW) A. tunisiana (Italy) and a New World (NW) population of A. franciscana (U.S.A.). Allozyme electrophoresis, discriminant analyses of morphometric characters, and laboratory tests for reproductive isolation were performed. Brine shrimp show a wide range of levels of both genetic variation and differentiation, based on 20 loci (mean $H_{\mathrm{e}}=0.058-0.108$; Nei's $\left.D=0.005-1.501\right)$. Mean genetic distance values are of an order usually associated with specific separation. Barriers to gene flow between EOW and WOW populations are not absolute as they are between Old World and New World populations. Among EOW populations no significant reproductive isolation was found, and high levels of genetic differentiation exist (mean $F_{\mathrm{ST}}=0.616$ ) despite minimal apparent reproductive isolation. However, discrimination based on morphometric characters within the EOW group clearly separates $A$. urmiana from the other populations. The use of male morphometric characters has proven at least as informative in correctly assigning individuals to the appropriate group as the more traditionally used female characters. There is no evident overall congruence between genetic, geographical and morphometric distances between the EOW populations studied.
\end{abstract}

Keywords: Artemia, bisexual, genetic differentiation, morphometrics, Old World.

\section{Introduction}

Brine shrimp (Artemia) are exceptionally suitable for the study of evolutionary processes such as speciation and genetic or morphometric differentiation (Browne \& Bowen, 1991). Many of the factors thought to be responsible for genetic differentiation and speciation in other organisms (see Barigozzi, 1982) are observable in Artemia: ecological isolation, formation of clines (in contents of heterochromatin), poly-, hetero- and aneuploidy, parthenogenesis (Abreu-Grobois, 1987; Barigozzi, 1989) and pre- or post-mating reproductive isolation (Browne et al., 1991). Relatively simple and identifiable environmental parameters also make Artemia ideal for the study of evolutionary adaptation (Bowen et al., 1988; Lenz \& Browne, 1991). Although distributed worldwide (in all continents except Antarctica), brine shrimp habitats are normally restricted to hypersaline inland lakes and coastal salterns (Vanhaecke et al., 1987). The genus is composed of a

${ }^{*}$ Correspondence. complex of diploid bisexual species (defined, to date, by the criterion of laboratory reproductive isolation) but also di-, tri-, tetra- and pentaploid multiclonal thelytokous species (of either automictic or apomictic type). These may be clustered under the binomen $A$. parthenogenetica, for taxonomic convenience.

Reproduction is exclusively sexual in the New World (Americas), from where three species have been described. Artemia persimilis (Piccinelli \& Prosdocimi, 1968 ) is restricted to four localities in Argentina (César, 1989). Artemia monica [or A. (franciscana) monica; Verril (1869)] is probably restricted to Mono Lake, CA., U.S.A. (Lenz, 1980). Artemia franciscana Kellogg (1906) is widely distributed throughout the American continent (Vanhaecke et al., 1987; Gajardo \& Beardmore, 1993).

Conversely, in the Old World both modes of reproduction as well as different asexual ploidy levels occur, sometimes sympatrically (Amat, 1980; Ahmadi et al., 1990; Browne et al., 1991; Lefcort et al., 1991; Zhang \& Lefcort, 1991). Bisexual populations are primarily confined to inland, athalassohaline lakes (i.e. those 
where the proportions of major anions are other than those of seawater), and have characteristically high rates of encystment and tolerance to cold temperatures.

To date, three Old World bisexual species of Artemia have been described. Artemia tunisiana (Bowen \& Sterling, 1978) is distributed in the Mediterranean region (southern Europe and North Africa). $A$. urmiana (Günther, 1900) seems to be restricted to Lake Urmia (Iran) and adjacent water bodies. A. sinica (Cai, 1989) is distributed in central and northern parts of China. However, in view of the lack of published data on tests of reproductive isolation, allozyme and morphometrical analyses, doubts have been cast on the validity of the binomen $A$. sinica by some workers (e.g. Abreu-Grobois, 1989; Browne, 1992).

In addition, Old World bisexual populations are believed, from phylogenetic inferences, to be the closest ancestor stock to all other Artemia, with $A$. urmiana inferred as the closest extant bisexual species to the parthenogenetic lineage (Abreu-Grobois, 1987).

In this paper we examine the extent of genetic variation and differentiation, as well as laboratory reproductive compatibility, of five previously unstudied Old World populations of bisexual Artemia, with special emphasis on Eastern Old World (EOW) populations. We assess whether natural barriers to gene flow, in the light of genetic variability and differentiation, are as strict as they seem to be among better-known species. We also assess discrimination based on morphometric variables for a subset of EOW populations, when cultured under standard conditions. Lastly, we test agreement between geographical, genetic and morphometric separation for three EOW species (Artemia sp., $A$. urmiana and $A$. sinica).

\section{Materials and methods}

\section{Artemia material}

Brine shrimp cyst samples used in this study come from natural collections of extant populations, and were obtained from three sources. The Laboratory for Aquaculture and Artemia Reference Centre (A.R.C., State University of Ghent, Ghent, Belgium) provided the $A$. franciscana (San Francisco Bay, Ca., U.S.A.; year batch 1988, A.R.C. no. 1090), Artemia sp. (Catvis, Kazakhstan, C.I.S.; 1988, A.R.C. no. 1039), A. sinica (Yuncheng, Shan-Xi, China; 1988, A.R.C. no. 1057) and Artemia sp. (Yimeng, China; 1991, A.R.C. no. 1188) samples. Dr G. Mura (Università La Sapienza, Rome, Italy) supplied the A. urmiana (Lake Urmia, Iran; 1988) sample and Professor C. Barigozzi (Università degli Studi di Milano, Milan, Italy) supplied the A. tunisiana (Quartu, Sardinia, Italy; 1990) sample.

\section{Stock culture conditions}

Cysts of each population were mass-hatched and cultured (2000 nauplii/10 L) under standard conditions of $24 \mathrm{~h}$ fluorescent lighting at room temperature $\left(21-23^{\circ} \mathrm{C}\right), 82-83$ p.p.t. salinity, and were fed baker's yeast (Sorgeloos et al., 1986; Clark \& Bowen, 1976; Browne et al., 1984).

\section{Breeding tests}

Reproductive compatibility was evaluated from singlepair reciprocal crosses of adult Artemia, for the majority of all possible combinations of populations for a period of 14-21 days. Virgin females had been isolated from the stock cultures for at least 14 days to ensure non-impregnation (female Artemia do not store sperm; Bowen, 1962). Males were collected directly from stock cultures. For some crosses, production of $\mathrm{F}_{2}$ and $\mathrm{F}_{3}$ as well as backcross generations was also analysed. Crosses were inferred to be fertile when live larvae (nauplii) or full cysts were produced (as opposed to no larvae or empty cysts). Viability of cysts was determined through their ability to hatch in standard conditions (after being stored dehydrated at $37^{\circ} \mathrm{C}$ for 2 weeks), following up to three cycles of hydration/ dehydration.

\section{Morphometric analyses}

Cyst diameters. Cysts of each of three EOW populations (A. sinica, A. urmiana, and Artemia sp. from Catvis, Kazakhstan) were hydrated, randomly collected and then measured (to the nearest $0.01 \mu \mathrm{m}$ ) under a light microscope equipped with a calibrated graticule. Differences in cyst diameter were assessed through an analysis of variance (and multiple comparisons of means using Duncan's procedure), run on the sPss-X statistical package (Norušis, 1990a,b), using a VAXDEC 8800 mainframe computer.

Adult body measurements. Cysts of each of three EOW populations (A. sinica, A. urmiana, and Artemia sp. from Catvis, Kazakhstan) were hatched. Two salinity values (62 and 82 p.p.t.) were used to rear individuals of each population. One hundred nauplii in $1 \mathrm{~L}$ of brine for each salinity and population were used. All flasks were kept under the same standard conditions of light $(24 \mathrm{~h})$ and temperature $\left(25 \pm 1^{\circ} \mathrm{C}\right)$.

After 35 days of culture, all surviving Artemia in each culture flask were lightly narcotized with a few drops of chloroform in brine (Gilchrist, 1960).

Measurements (to the nearest $0.1 \mu \mathrm{m}$ ) of eight quantitative characters (total length, abdominal length, 
Table 1 Intraspecific and interspecific crosses between bisexual Old World and New World Artemia. Superscript numbers in parentheses indicate the number of fertile crosses of the previous generation from which pairs were drawn

\begin{tabular}{|c|c|c|c|c|}
\hline \multirow[b]{2}{*}{$9 / 0^{\circ}$} & \multicolumn{4}{|c|}{ Type of cross (fertile/total) } \\
\hline & Parental & $\mathrm{F}_{1}$ & $\mathrm{~F}_{2}$ & Backcross \\
\hline SFB (control) & $9 / 10$ & $6 / 6^{(6)}$ & N.T. & N.T. \\
\hline TUN (control) & $4 / 4$ & $1 / 1^{(1)}$ & N.T. & N.T. \\
\hline RUS (control) & $11 / 12$ & $8 / 8^{(3)}$ & $3 / 3^{(1)}$ & $O F_{1} \times O^{\prime} \mathrm{P} 1 / 1$ \\
\hline $\mathrm{SIN}$ (control) & $14 / 15$ & $13 / 16^{(1)}$ & $31 / 32^{(7)}$ & $\begin{array}{l}{ }_{F_{1}} \times{ }^{\prime} \mathrm{P} 1 / 1 \\
o \mathrm{~F}_{1} \times \wp \mathrm{P} 1 / 1\end{array}$ \\
\hline $\mathrm{URM}$ (control) & $10 / 12$ & $7 / 8^{(3)}$ & $3 / 4^{(2)}$ & $\mathrm{OF}_{1} \times \odot \mathrm{P} 1 / 1$ \\
\hline YIM (control) & $6 / 7$ & $2 / 3^{(1)}$ & N.T. & N.T. \\
\hline SFB/RUS & $0 / 24$ & - & - & - \\
\hline RUS/SFB & $0 / 22$ & - & - & - \\
\hline SFB/SIN & $1 / 16$ & $0 / 1$ & - & - \\
\hline SIN/SFB & $0 / 19$ & - & - & - \\
\hline URM/SFB & $0 / 6$ & - & - & - \\
\hline SFB/URM & $0 / 5$ & - & - & - \\
\hline URM/TUN & $0 / 2$ & - & - & - \\
\hline TUN/URM & $0 / 5$ & - & - & - \\
\hline SIN/TUN & $1 / 3$ & N.T.* & - & $\mathrm{OF}_{1} \times \subsetneq \mathrm{P} 0 / 1$ \\
\hline TUN/SIN & $0 / 1$ & - & - & - \\
\hline RUS/TUN & $0 / 1$ & - & - & - \\
\hline TUN/RUS & $1 / 5$ & N.T. & - & - \\
\hline SIN/RUS & $12 / 16$ & $5 / 6^{(1)}$ & $2 / 2^{(1)}$ & 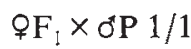 \\
\hline RUS/SIN & $16 / 22$ & $18 / 21^{(4)}$ & $3 / 6^{(1)}$ & N.T. \\
\hline URM/RUS & $6 / 8$ & $6 / 7^{(2)}$ & $2 / 2^{(2)}$ & N.T. \\
\hline RUS/URM & $3 / 6$ & $9 / 9^{(2)}$ & $2 / 3^{(1)}$ & N.T. \\
\hline URM/SIN & $3 / 7$ & $5 / 6^{(2)}$ & $2 / 3^{(1)}$ & N.T. \\
\hline SIN/URM & $13 / 18$ & $9 / 10^{(2)}$ & $4 / 5^{(2)}$ & @F $\times{ }^{\prime} \mathrm{P} 1 / 1$ \\
\hline SIN/YIM & $6 / 7$ & N.T. & - & - \\
\hline YIM/SIN & $2 / 2$ & N.T. & - & - \\
\hline YIM/RUS & $2 / 3$ & N.T. & - & - \\
\hline RUS/YIM & $2 / 2$ & N.T. & - & - \\
\hline YIM/URM & $2 / 2$ & N.T. & - & - \\
\hline URM/YIM & $1 / 2$ & N.T. & - & - \\
\hline
\end{tabular}

*Thirteen nauplii were produced, of which six males survived to maturity. $\mathrm{P}=$ parent, N.T. $=$ not tested, $\mathrm{RUS}=$ Artemia $\mathrm{sp} .($ Catvis $), \mathrm{YIM}=$ Artemia $\mathrm{sp}$. (Yimeng), $\mathrm{SFB}=A$. franciscana, $\mathrm{TUN}=A$. tunisiana, $\mathrm{URM}=A$. urmiana, $\mathrm{SIN}=A$. sinica.

abdominal width, length of furca, head width, distance between complex eyes, diameter of eyes, length of the first antenna) and one meristic character (total number of furcal setae) in males and females, and width of ovisac in females were made under a light microscope. All measurement variables were found to have high repeatability (measurement error was assessed for a random subset of specimens measured three times). Description of female measurement variables follows that of Hontoria \& Amat (1992a, b), except that total number of furcal setae is used here (instead of left and right lobe numbers), and the ratio of abdominal length to total length is not used, due to several conceptual difficulties with the use of ratios, which may seriously affect interpretation of results (see Humphries et al., 1981). Measurement variables in males follow the description of Pilla (1992). Because discriminant analysis performs optimally when the variables used are normally distributed, continuous measurement variables found to deviate from normality (by means of the Lilliefors test, Norušis, 1992a) were normalized through a $\log _{10}$ transformation. The total number of setae was square-root transformed. 
In order to explore multivariate morphometric relationships between groups, four different discriminant-function analyses (one for each sex and salinity) were performed with sPss-x (Norušis, 1990a,b), on the VAX-DEC 8800. In each analysis a forward stepwise variable selection method was employed (see Norušis, $1990 \mathrm{a}, \mathrm{b})$ in order to choose the smallest possible set of useful predictor variables to build the function. Finally, the percentage of individuals correctly assigned to their original population on the basis of their discriminantfunction scores was calculated. A complete description of the techniques used is given in Tatsuoka (1971).

\section{Protein electrophoresis}

Approximately equal numbers of randomly drawn adult males and females (43-92 from each population) from the stock cultures were used for allozyme analyses. Allozyme variation was assayed using standard starch-gel $(12.5 \%)$ electrophoresis. A total of 14 enzymes encoded by 20 loci (Enzyme Commission numbers follow IUBNC, see Ward et al., 1992) were analysed: amylase (AMY-1; E.C. 3.2.1.1), aspartate aminotransferase (AAT-1, AAT-2; E.C. 2.6.1.1), esterases (EST-1, EST-4; E.C. 3.1.1.-), esterase-D (EST-D; E.C. 3.1.1.-), isocitrate dehydrogenase (IDH-1, $I D H-2$; E.C. 1.1.1.42), $l$-lactate dehydrogenase ( $L D H-1$; E.C. 1.1.1.27), leucine aminopeptidase ( $L A P-2, L A P-3$; E.C. 3.4.11.1), malate dehydrogenase ( $M D H-1, M D H-$ 2; E.C. 1.1.1.37), NADP-malate dehydrogenase (MEZ1; E.C. 1.1.1.40), peptidase (PEP-1, PEP-4; E.C. 3.4.11.-), glucosephosphate isomerase (GPI-1; E.C. 5.3.1.9), phosphoglucomutase (PGM-1; E.C. 5.4.2.2), phosphogluconate dehydrogenase (6PGD-1; E.C. 1.1.1.44) and superoxide dismutase (SOD-1; E.C. 1.15.1.1). Homogenates of whole individual Artemia were electrophoresed according to methods described by Abreu-Grobois \& Beardmore (1980). Staining of gels followed methods from Shaw \& Prasad (1970) and Harris \& Hopkinson (1976), with some modifications.
Allozyme variation. All statistical analyses on allozyme data were performed with the PC version of the computer package Bıosys-1 release 1.7 (Swofford \& Selander, 1981). Two estimates of heterozygosity were calculated: the observed heterozygosity (Ferguson, 1980), and the unbiased estimate of expected heterozygosity, calculated from Hardy-Weinberg expectations (Nei, 1978). The percentage of polymorphic loci (0.99 criterion) and the number of alleles per locus were also calculated for each population. A matrix of genetic similarities for pairwise comparisons between all populations was obtained from the genetic distance and identity of Nei (1972), and an UPGMA dendrogram of Nei's genetic distance between populations was constructed. Genetic structuring within and between populations was estimated using Wright's (1978) Fstatistics. Wright's formula for the overall fixation index $\left(F_{\text {IT }}\right)$ due to combined effects of inbreeding within each (sub)population and random genetic drift between populations is

$\left(1-F_{\mathrm{IT}}\right)=\left(1-F_{\mathrm{IS}}\right)-\left(1-F_{\mathrm{ST}}\right)$,

where $F_{\text {IS }}$ is the subpopulation inbreeding coefficient. $F_{\mathrm{ST}}$ measures the proportion of overall genetic variance attributable to differences between populations. Significance of levels of allelic heterogeneity measured by single-locus $F_{\mathrm{ST}}$ values was tested by a chi-squared transformation (Waples, 1987). Significance of the mean $F_{\text {ST }}$ value was evaluated by a chisquared test over all loci (O'Connell, 1993).

\section{Results}

\section{Laboratory reproductive isolation}

Population codes and data from tests for reproductive isolation are listed in Table 1 . The results reveal that, with one exception (a female $A$. franciscana and a male $A$. sinica pair generated two sterile $\mathrm{F}_{1}$ offspring), complete infertility exists between all Old World popula-

Table 2 Summary of genetic variability in bisexual Old World and New World species of Artemia

\begin{tabular}{lcccc}
\hline & & & \multicolumn{2}{c}{ Heterozygosity } \\
\cline { 5 - 5 } $\begin{array}{c}\text { Mean no. of } \\
\text { alleles/locus }\end{array}$ & $P$ & Observed & Expected \\
\hline A. franciscana & $1.4(0.1)$ & 30 & $0.049(0.027)$ & $0.058(0.031)$ \\
A. tunisiana & $1.6(0.2)$ & 35 & $0.057(0.028)$ & $0.075(0.039)$ \\
Artemia sp. RUS & $2.0(0.2)$ & 60 & $0.096(0.033)$ & $0.108(0.037)$ \\
A. sinica & $2.0(0.3)$ & 55 & $0.097(0.033)$ & $0.097(0.033)$ \\
A. urmiana & $2.3(0.3)$ & 65 & $0.080(0.024)$ & $0.096(0.028)$ \\
Artemia sp. YIM & $1.9(0.2)$ & 55 & $0.084(0.035)$ & $0.095(0.037)$ \\
\hline
\end{tabular}

Numbers in parentheses are standard errors, $P=$ percentage polymorphic loci $\langle 0.99$ criterion). Population codes as in Table 1. 
tions tested and New World $A$. franciscana. These results support the view that reproductive isolation between Old and New World bisexual brine shrimp is a prominent feature in the evolution of these species (Abreu-Grobois, 1987).

Among Old World populations, crosses performed between the representative population of the European A. tunisiana species with other (Eastern) Old World populations were also either all completely infertile $(A$. tunisiana $\times A$. urmiana $)$ or largely so $(A$. tunisiana $\times A$. sinica and Artemia sp. RUS). This is a result of substantial post-mating isolating barriers at the laboratory level, since pairing was always observed.

When matings between EOW populations are considered (Artemia sp. YIM was not included in the comparisons due to lack of material), the proportion of interpopulation crosses which is fertile $(63.8 \pm 13.9$ per cent) is lower than that of the intrapopulation controls $(88.5 \pm 4.8$ per cent). However, this difference is not significant $\left(\chi_{3}^{2}=2.5 ; P>0.30\right)$. There was also no apparent hybrid breakdown at later generations (production of $\mathrm{F}_{2}$ and $\mathrm{F}_{3}$ ) or infertility in a few backcrosses tested. These results indicate that post-mating barriers to gene flow between these populations are likely, under the laboratory conditions employed (e.g. artificial medium), to be weak.

\section{Morphometrics}

Cyst size. Between 823 and 1060 cysts of each of three EOW populations (Artemia sp. RUS, $A$. sinica and $A$. urmiana) were measured. Mean cyst sizes differ very significantly between the three populations $\left(F_{2,2733}=1854.01 ; P<0.001\right)$. Cysts of $A$. urmiana are the largest $(265.82 \pm 15.85 \mu \mathrm{m})$. Duncan's test for multiple comparisons of means indicates that cyst diameters of Artemia sp. (RUS) and A. sinica $(230.05 \pm 15.41 \mu \mathrm{m}$ and $232.75 \pm 11.22 \mu \mathrm{m}$, respectively) are also significantly different $(P<0.01)$ from each other.

Adult body size. A total of 152 females and 124 males were recovered from cultures at both salinities. Two discriminant functions resulted from each of the four discriminant analyses performed on each sex and salinity between three EOW populations (Artemia sp. RUS, $A$. sinica, and $A$. urmiana). A test of the null hypothesis that the means of the discriminant functions between all populations are equal and 0 (in which case the functions would only reflect sampling variability) is tested using a chi-squared transformation of Wilk's lambda (Norušis, 1992b). In all four analyses, both functions are highly significantly different from 0 $(P<0.001)$. The separation between populations is
Table 3 Wright's (1978) $F$-statistics for four EOW Artemia populations. Significance of single-locus and overall $F_{\text {ST }}$ values were tested by chi-square transformations (see text)

\begin{tabular}{lrrr}
\hline Locus & \multicolumn{1}{c}{$F_{\text {IS }}$} & \multicolumn{1}{c}{$F_{\text {IT }}$} & \multicolumn{1}{c}{$F_{\text {ST }}$} \\
\hline$A A T-1$ & 0.227 & 0.403 & $0.227^{* * *}$ \\
$A A T-2$ & 0.371 & 0.953 & $0.926^{* * *}$ \\
$E S T-D$ & -0.033 & -0.017 & $0.015^{* *}$ \\
$G P I-1$ & -0.003 & 0.575 & $0.577^{* * *}$ \\
$I D H-1$ & 0.160 & 0.451 & $0.347^{* * *}$ \\
$I D H-2$ & 0.035 & 0.567 & $0.552^{* * *}$ \\
$L A P-2$ & -0.014 & 0.970 & $0.970^{* * *}$ \\
$L A P-3$ & 0.103 & 0.904 & $0.893^{* * *}$ \\
$L D H-1$ & -0.011 & -0.003 & $0.008 \mathrm{NS}$ \\
$M D H-1$ & 0.150 & 0.151 & $0.002 \mathrm{NS}$ \\
$M D H-2$ & 0.138 & 0.749 & $0.709^{* * *}$ \\
$P E P-1$ & -0.006 & 0.994 & $0.994^{* * *}$ \\
$P E P-4$ & 0.291 & 0.323 & $0.046^{* * *}$ \\
$P G M-1$ & 0.035 & 0.583 & $0.567^{* * *}$ \\
$6 P G D H-1$ & 0.033 & 0.106 & $0.075^{* * *}$ \\
Mean & 0.089 & 0.651 & $0.616^{* * *}$ \\
\hline
\end{tabular}

NS $=$ not significant $(P>0.05),{ }^{* *}=P \leqslant 0.01$, $* * *=P \leqslant 0.001$.

graphically represented by the plots of each cloud of discriminant scores (Fig. 1). The first discriminant function is responsible for most of the variance in all analyses. Thus, at 62 p.p.t. salinity the first discriminant function is responsible for 93.5 and 90.7 per cent of the total variance in males and females, respectively. For cultures kept at 82 p.p.t., 92.4 per cent of the total variance in males and 71.8 per cent in females is accounted for by the first function.

The mean overall discrimination between populations at the different salinity levels is high for both sexes, compared to what is expected by chance alone (33.3. per cent). Values range from 96.7 to 100 per cent of cases correctly classified to their own population (overall mean for males $=99$ per cent, overall mean for females $=97.5$ per cent ) .

Genetic variation and differentiation. Brine shrimp characteristically display high levels of genetic variability (summary in Table 2). Mean numbers of alleles per locus, percentage polymorphic loci and heterozygosity range from 1.4 to $2.3,30$ to 65 per cent, and 5.8 to 10.8 per cent, respectively. Values are especially high for Old World populations, with $A$. urmiana possessing both the highest mean number of alleles per locus (2.3) and percentage polymorphic loci (65 per cent), and $A$. sinica showing the largest heterozygosity value $(9.7$ per 
a)

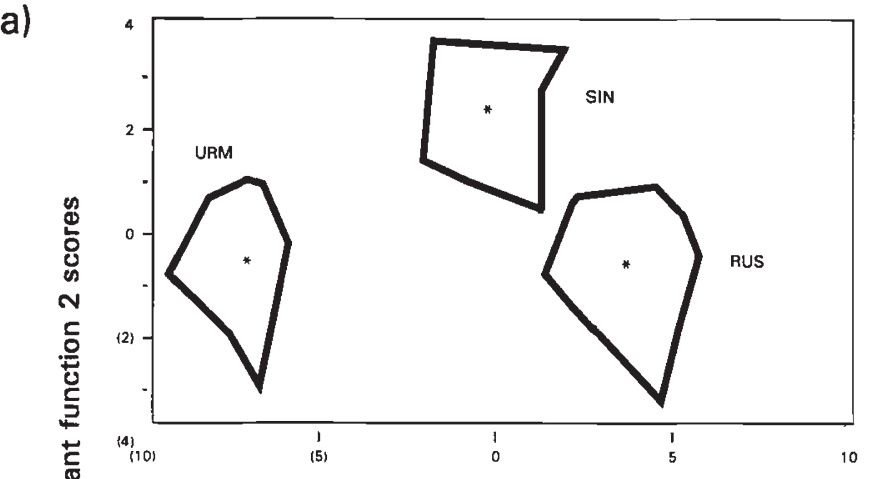

c)

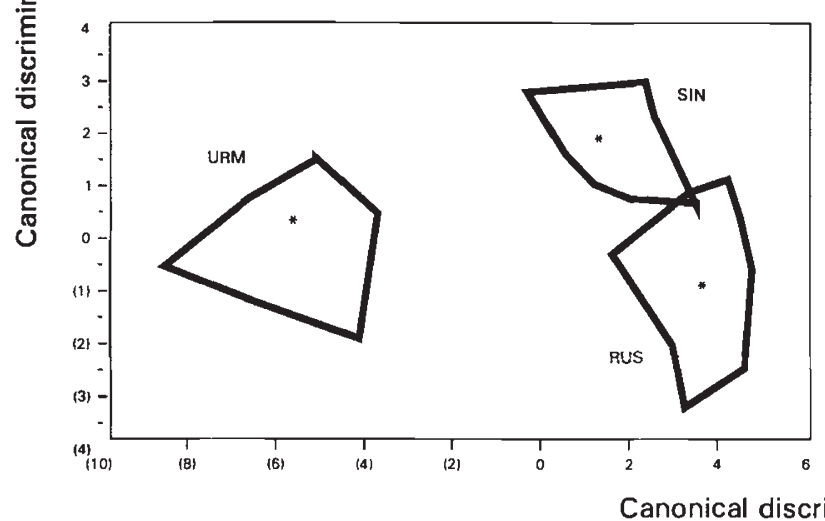

b)

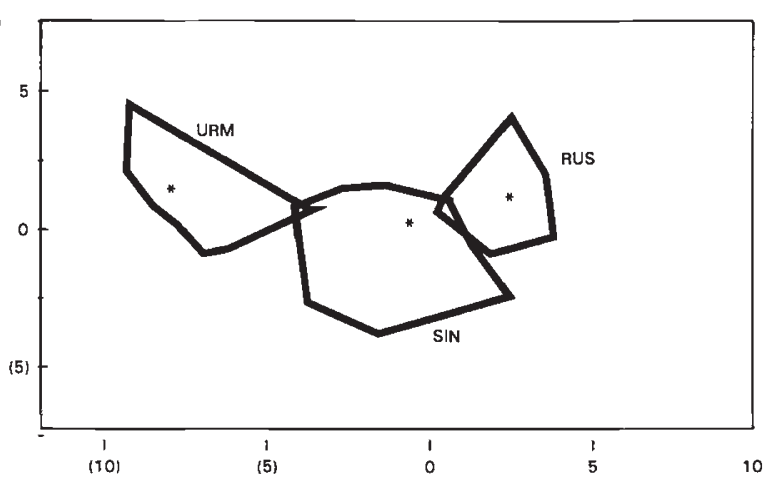

d)

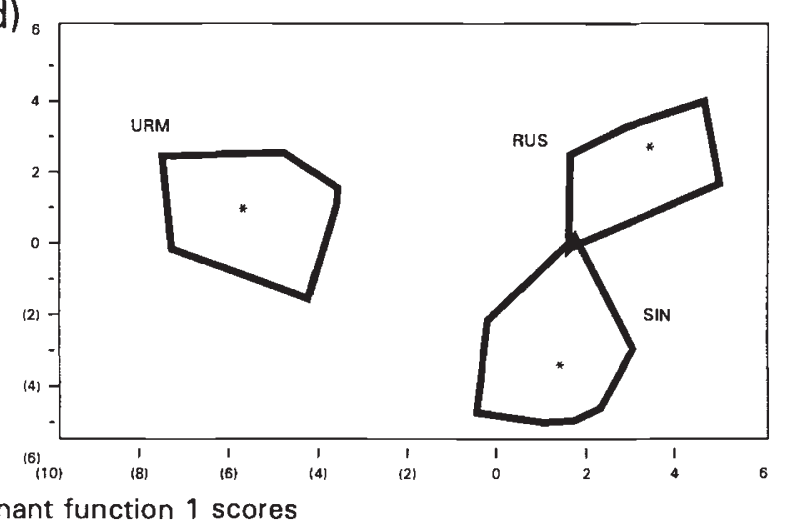

Fig. 1 Scatterplots of individual discriminant function scores (polygons are obtained by joining the outermost cases of each cloud of points) for each sex and salinity. (a) Males and (b) females from populations grown at 62 p.p.t.; (c) males and (d) females from populations grown at 82 p.p.t. Population codes as in Table 1. Asterisks indicate cloud centroids.

cent). Values of genetic variation observed for the heavily commercially exploited San Francisco Bay $A$. franciscana population are atypical of the species as a whole, being among the lowest of those seen in many populations analysed (Abreu-Grobois, 1983).

Table 3 lists interpopulation single-locus values of $F_{\text {IS }}, F_{\text {IT }}$ and $F_{\text {ST }}$ for those populations found to interbreed freely in the laboratory $(A$. urmiana, $A$. sinica, Artemia sp. RUS and Artemia sp. YIM). The mean $F_{\mathrm{IT}}$ value is quite large (0.651) and is due mostly to a very high value of $F_{\mathrm{ST}}$. More than 65 per cent of loci show $F_{\text {ST }}$ values greater than $0.2(50$ per cent of loci have $\left.F_{\mathrm{ST}}>0.5\right)$, and the majority of chi-squared comparisons (all except $L D H-1$ and $M D H-1$ ) are highly significantly different from zero. The resulting mean $F_{\mathrm{ST}}$ value $(0.616)$ is therefore also highly significantly different from zero and indicates very substantial systematic subdivision in these populations. In other words, approximately 62 per cent of the allozyme heterogeneity is due to interpopulation differences.

The calculated genetic distances (and identities) between populations are given in Table 4 . In agreement with previous studies (see Abreu-Grobois, 1987), very large genetic distances exist between New World and Old World Artemia ( $D$ values ranging from 0.74 to 1.5), representing an almost complete allozyme turnover. The magnitude of these distances is consistent with the congeneric status of these species. Congeneric genetic distances between the Western and Eastern Old World populations are also quite large (values of $D$ ranging from 0.58 to 0.86 ), indicating very extensive divergence.

Among EOW populations, $D$ values range from 0.005 (A. sinica and Artemia sp. YIM) to up to 0.36 ( $A$. sinica and $A$. urmiana), with a mean value of 0.27 $(\mathrm{SE}=0.06)$. However, in view of the very small distance between the two (conspecific) Chinese populations $A$. sinica and Artemia sp. (YIM), the mean distance value between all EOW populations is recalculated with both Chinese populations analysed separately. The resulting mean increases to 0.32 $(\mathrm{SE}=0.03)$ and $0.31(\mathrm{SE}=0.03)$, when $A$. sinica and Artemia sp. (YIM), respectively, are left out of the calculation. 
Table 4 Matrix of pairwise Nei's genetic identity ( $I$, below diagonal $)$ and distance ( $D$, above diagonal) between Old World and New World bisexual species of Artemia. Population codes as in Table 1

\begin{tabular}{lcccccc}
\hline & 1 & 2 & 3 & 4 & 5 & 6 \\
\hline 1. A. franciscana & - & 1.501 & 0.885 & 0.916 & 0.737 & 0.936 \\
2. A. tunisiana & 0.223 & - & 0.583 & 0.868 & 0.664 & 0.859 \\
3. Artemia sp. RUS & 0.413 & 0.558 & - & 0.345 & 0.249 & 0.339 \\
4. A. sinica & 0.400 & 0.420 & 0.708 & - & 0.355 & 0.005 \\
5. A. urmiana & 0.478 & 0.515 & 0.779 & 0.701 & - & 0.346 \\
6. Artemia sp. YIM & 0.392 & 0.424 & 0.712 & 0.995 & 0.708 & - \\
\hline
\end{tabular}

Fig. 2 UPGMA dendrogram of Nei's (1972) genetic distance between bisexual Artemia species.
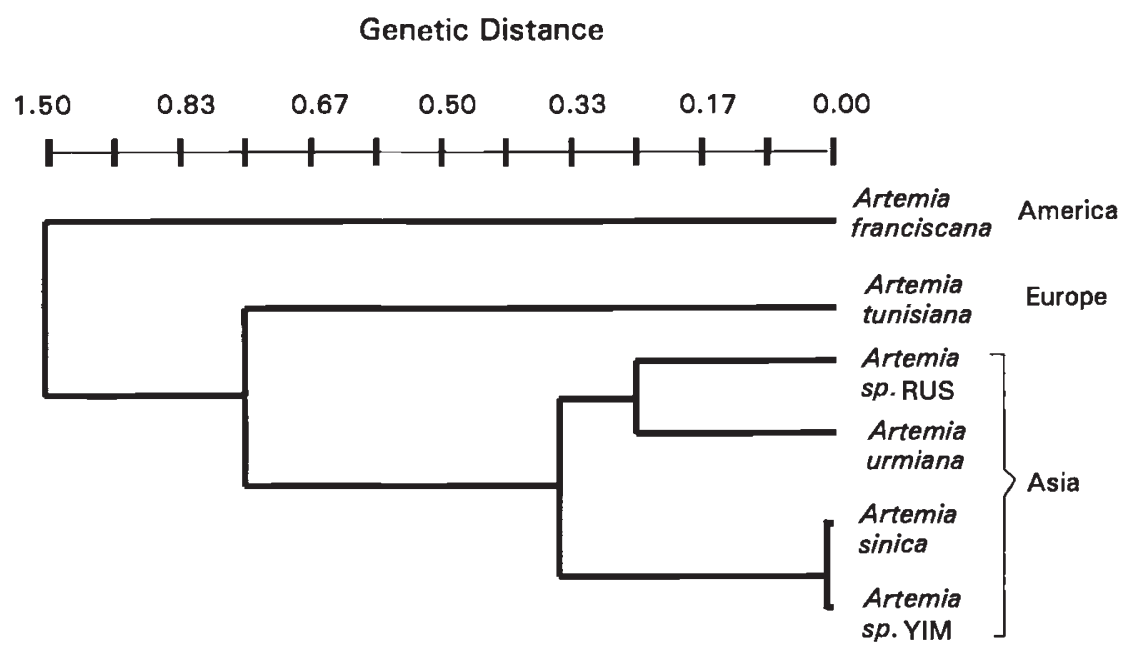

The UPGMA dendrogram (Fig. 2) shows the graphical representation of genetic distances between populations. The relative positions of both $A$. franciscana and $A$. tunisiana in relation to $A$, urmiana conform to published estimates (see Abreu-Grobois, 1987). The overall branching pattern seen with genetic distances seems to parallel closely the geographical separation between these species, i.e. European, American and Asian species occupy branches of clearly distinct depths.

\section{Discussion}

This and other allozyme studies on bisexual Artemia have revealed levels of genetic variation which are unusually high for a crustacean genus. Average values of heterozygosity, percentage polymorphic loci and number of alleles per locus are comparable with values found in more genetically variable invertebrate classes such as insects and molluscs (Abreu-Grobois, 1987; Ward et al., 1992).
In addition, some mean estimates of levels of genetic substructuring and differentiation are even higher than those calculated for a variety of invertebrate species. Thus, substantial $F_{\mathrm{ST}}$ values have been calculated for several conspecific $A$. franciscana $\left(F_{\mathrm{ST}}=0.24\right)$ and $A$. tunisiana $\left(F_{\mathrm{ST}}=0.12\right)$ populations from previous studies (Abreu-Grobois \& Beardmore, 1982; AbreuGrobois, 1987). For A. franciscana, genetic substructuring is highest among South American populations $\left(F_{\mathrm{ST}}=0.38 ;\right.$ G. Gajardo et al., unpublished data). Hence, an extremely high value of $F_{\mathrm{ST}}(0.616)$ between the EOW populations studied is indicative of extensive genetic differentiation between gene pools, and suggests little if any gene flow between these isolates. In comparison, a review on the extent of population subdivision in several invertebrate taxa reveals mean $F_{\mathrm{ST}}$ values much smaller than those found for EOW $A r$ temia, such as 0.17 for crustaceans, 0.26 for molluscs, 0.10 for insects and a grand mean (compiled from 114 species) of 0.17 for all invertebrates (Ward et al., 1992). 
Genetic distance values between EOW populations $(D=0.31-0.32)$ fall well within, although at the lower end of, the calculated congeneric scale for the genus. In addition, as expected, they are well above conspecific estimates for several populations of $A$. franciscana and A. tunisiana ( 0.13 and 0.09 , respectively) from earlier studies (Abreu-Grobois, 1983, 1987). As a whole the genus has $D$ values ranging from an astonishing 2.77 (A. franciscana vs. A. tunisiana) to less than 0.10 ( $A$. franciscana vs. A. monica). Among Crustacea it is estimated that, for the majority of congeneric comparisons, values of $D$ fall between 0.22 and 1.2 , with a mean of 0.53 (Hedgecock et al., 1982).

Reproductive (as opposed to geographical) barriers to gene flow are well established between species in the New World and between those and Old World species. It is postulated that the dispersal mechanisms of Artemia (which are reputedly assisted by migratory waterfowl), and the nature of the scattered and relatively isolated biotopes it inhabits have generated conditions propitious for maximal interpopulational genetic differentiation. These conditions would also tend to maximize genetic drift. Conversely, differentiation seems to be most marked when populations inhabit 'non-typical' (i.e. of chemical composition relatively unlike that of seawater) environments (AbreuGrobois, 1983), suggesting an important role for selection and adaptation. It is also believed that a continuous and gradual build-up of isolating barriers may have ultimately led to reproductive and/or ecological isolation between populations and species (AbreuGrobois, 1987). Recent laboratory evidence seems to support this hypothesis (Bowen et al., 1985, 1988; Browne \& Bowen, 1991). Nevertheless, in some cases reproductive or ecological isolation seems to be associated, from inferences on genetic distances, with a small number of loci (e.g. $A$. franciscana and $A$. monica; Abreu-Grobois, 1987).

Among species inhabiting the Old World the situation seems more complex, since there is minimal (laboratory) reproductive isolation between geographically wide apart and genetically very distinct EOW populations. From allozyme data it is inferred that species in the New World have diverged further away in time from a common ancestral Artemia than those in the Old World (Beardmore \& Abreu-Grobois, 1983). This may suggest, in turn, that development of barriers to gene exchange through selective pressure and genetic drift has not yet been perfected for some species in the Old World or that, for some yet unknown reason, allozymes are evolving rapidly there.

Lack of such barriers to laboratory reproductive isolation undermines the universality and reliability of tests for reproductive isolation, widely used in the past on Artemia studies, as primary criteria for inference of the species status of previously uncharacterized populations. Moreover, it has been shown in the present study that even genetically extremely distinct and allopatric species can, albeit very rarely, produce laboratory hybrids $(A$. franciscana with $A$. sinica, A. tunisiana with $A$. sinica and Artemia sp. RUS). The matter of specific status in Artemia is somewhat undermined by geography. However, the use of genetic distance values calibrated from widely different and completely unrelated taxa as estimates of species isolation may not be any better than mating experiments alone.

Multivariate approaches to morphometric discrimination between populations have only recently been employed in Artemia research (Hontoria \& Amat, 1992a,b). In addition, they can be of use either when there is no prominent morphological distinction between populations, or when the reliability of a set of morphometrical variables is being tested against other discriminating criteria, such as allozymes. Nevertheless, whenever bisexual populations were analysed, only female characters were taken into consideration. In the present study, overall discrimination based on male characaters was better than that based on female ones, attesting to the usefulness of male traits in this type of analysis. As a result, for A. urmiana, discrimination based on the output of morphometric analyses (i.e. adult body size and cyst diameter) is congruent with other, qualitative (i.e. shape) differences observed for the same species evaluated elsewhere (Pilla, 1992). This finding also holds at different salinity levels. Conversely, discrimination between $A$. sinica and Artemia sp. (RUS) from Kazakhstan relies more heavily on size than shape, which is also reflected in the analysis of cyst sizes. This underlies the morphometric closeness between these two populations.

There is no apparent large-scale congruence between the three possible scales of genetic, morphometric and geographical distances for EOW species, though some similarities are evident (Fig. 3). Thus, between A. urmiana and Artemia sp. (RUS) geographical and genetic distances seem to parallel each other closely. However, when separation between these species and $A$. sinica is compared, genetic distances do not correspond to geographical ones (the latter are especially higher between $A$. sinica and $A$. urmiana). In contrast, morphometric distance clearly separates $A$. urmiana from the other two species.

\section{Acknowledgements}

The authors express their appreciation to Drs R. A. Browne, G. R. Carvalho, D. O. F. Skibinski, M. O'Connell and R. I. Lewis, and an anonymous referee, 

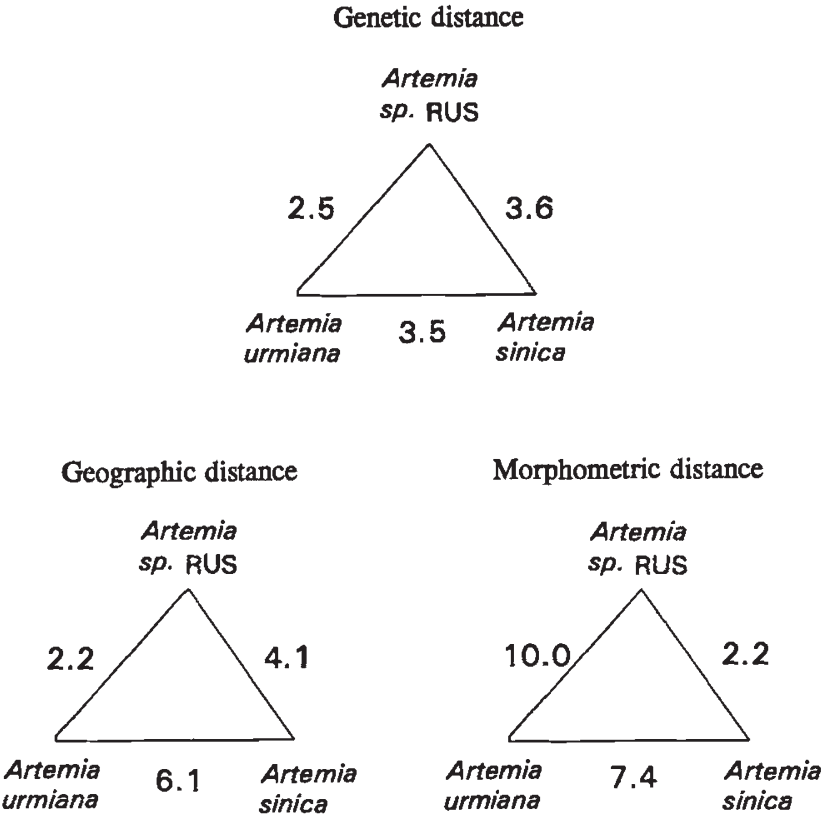

Fig. 3 Comparison between genetic, morphometric and geographical separation between three EWO species (codes as in Table 1). Geographical distances $\left(\times 10^{3} \mathrm{~km}\right)$ are estimated from straight-line transects. Genetic distances are Nei's $D(\times 10)$. Morphometric distances (1 Euclidean unit $=1 \mathrm{~cm}$ ) are measured between averaged (per sex and salinity) population centroids.

for their helpful criticism and useful suggestions on earlier drafts of the manuscript, and to Mrs K. Thomas, who proofread it. We are also grateful to people who provided cysts for this study. P. Sorgeloos and his staff at the Laboratory for Aquaculture and Artemia Reference Center gave invaluable encouragement and support. This research is partially financed by an EEC project TS2-CT91-0331 (DSCN) and arises from a collaborative framework between the Universities of Ghent (Belgium), Swansea (United Kingdom), Milan (Italy) and the Salt Research Institute (China). E.J.S.P. was funded by a Ph.D. studentship CAPES-4531/88-5 provided by the Brazilian Government and a University of Wales Research Fellowship.

\section{References}

Abreu-grobols, F. A. 1983. Population Genetics of Artemia. Ph.D. Thesis, University College Swansea, U.K. ABREU-GRoBoIs, F. A. 1987. A review of the genetics of Artemia. In: Sorgeloos, P., Bengtson, D. A., Decleir, W. and Jaspers, E. (eds) Artemia Research and its Applications, vol. 1: Morphology, Genetics, Strain Charac- terization, Toxicology, pp. 61-99. Universa Press, Wetteren, Belgium.

ABREU-GroboIS, F. A. 1989. Observations and questions with regard to Artemia taxonomy. Artemia Newsletter, 12, 5-8.

ABREU-GROBOIS, F. A. AND BEARDMORE, J. A. 1980. International study on Artemia: II. Genetic characterization of Artemia populations - an electrophoretic approach. In: Persoone, G., Sorgeloos, P., Roels, O. and Jaspers, E. (eds) The Brine Shrimp Artemia, vol. 1: Morphology, Genetics, Radiobiology, Toxicology, pp. 133-146. Universa Press, Wetteren, Belgium.

ABREU-GroboIs, F. A. AND BEARDMORE, J. A. 1982. Genetic differentiation and speciation in the brine shrimp Artemia. In: Barigozzi, C. (ed.) Mechanisms of Speciation, pp. 345-376. Alan R. Liss, New York.

AHMADI, M. R., LeIbovitz, H. AND SIMPSON, K. 1990. Characterization of Uromiah Lake Artemia (Artemia uromiana) by isoelectrofocusing of isozyme patterns. Comp. Biochem. Physiol., 95, 115-118.

AMAT, F. 1980. Differentiation in Artemia strains from Spain. In: Persoone, G., Sorgeloos, P., Roels, O. and Jaspers, E. (eds) The Brine Shrimp Artemia, vol. 1: Morphology, Genetics, Radiobiology, Toxicology, pp. 19-39. Universa Press, Wetteren, Belgium.

BARIGOZZI, C. 1982. Mechanisms of speciation. Alan R. Liss, New York.

BARIGOZZI, C. 1989. Cytogenetics and speciation of the brine shrimp Artemia. Atti Accad. Lincei Mem. Fis. XIX, S. VIII Sez. III, 58-81.

BEARDMORE, J. A. AND ABREU-GRoboIs, F. A. 1983. Taxonomy and evolution in the brine shrimp Artemia. In: Oxford, G. S. and Rollinson, D. (eds) Protein Polymorphism: Adaptive and Taxonomic Significance, pp. 153-164. Academic Press, New York.

Bowen, s. T. 1962. The genetics of Artemia salina: I. The reproductive cycle. Biol. Bull., 122, 25-32.

BOWEN, S. T. AND STERLING, G. S. 1978. Esterase and malate dehydrogenase isozyme polymorphism in 15 Artemia populations. Comp. Biochem. Physiol., 61, 593-595.

Bowen, s. T., BUONCRIstiani, M. R. AND CARL, J. R. 1988. Artemia habitats: ion concentrations tolerated by one superspecies. Hydrobiologia, 158, 201-214.

BOWEN, S. T., FOGARINI, E. A., HITCHNER, K. N., DANA, G. L., CHOW, V. H. S., BUONCRISTIANI, M. R. AND CARL, J. R. 1985. Ecological isolation in Artemia: population differences in tolerance of anion concentrations. J. Crust. Biol., 5, 106-129.

BROWNE, R. A. 1992. Population genetics of Artemia: insights into parthenogenetic reproduction. Trends Ecol. Evol., 7, 232-237.

BROWNE, R. A. AND BOWEN, S. T. 1991. Taxonomy and population genetics of Artemia. In: Browne, R. A., Sorgeloos, P. and Trotman, C. A. (eds) Artemia Biology, pp. 221-236. CRC Press, Boca Raton, FL.

BROWNE, R. A., LI, M., WANIGASEKERA, G., SIMONEK, S., BROWNLEE, D., EIBAND, G. AND COWAN, J. 1991. Ecological, physiological and genetic divergence of sexual and asexual (diploid and polyploid) brine shrimp (Artemia). Adv. Ecol., 1, 41-52.

BROWNE, R. A., SALLEE, S. E., GROSCH, D., SEGRETI, W. AND PURSER, S. 1984. Partitioning genetic and environmental components 
of reproduction and lifespan in Artemia. Ecology, 65, 949-960.

CAI, Y. 1989. A redescription of the brine shrimp (Artemia sinica). Wasmann J. Biol., 47, 105-110.

CÉSAR, I. I. 1989. Geographic distribution of the Anostracans (Crustacea) in Argentina (South America). Stud. Neotrop. Fauna Envir., 24, 183-188.

Clark, L. S. And Bowen, s. T. 1976. The genetics of Artemia salina. VII. Reproductive isolation. J. Hered., 67, 385-388.

FERGUSON, A. 1980. Biochemical Systematics and Evolution. Blackie \& Son, Glasgow.

GAJARDO, G. M. AND BEARDMORE, J. A. 1993. Electrophoretic evidence suggests that the Artemia found in the Salar de Atacama, Chile, is Artemia franciscana Kellogg. Hydrobiologia, 257, 65-71.

GILCHRIST, B. M. 1960. Growth and form of the brine shrimp Artemia (L.). Proc. Zool. Soc. Lond., 134, 221-235.

GÜNTHER, R. T. 1900. Contributions to the natural history of Lake Urmia, N.W. Persia and its neighbourhood. J. Linnaean Soc. Zool., 27, 345-452.

HARRIS, H. AND HOPKINSON, H. 1976. Handbook of Enzyme Electrophoresis in Human Genetics. North-Holland, Amsterdam.

HEDGECOCK, D., TRACEY, M. L. AND NELSON, K. 1982. Genetics. In: Abele, L. G. (ed.) The Biology of Crustacea, pp. 283-403. Academic Press, New York.

HONTORIA, F. AND AMAT, F. 1992a. Morphological characterization of adult Artemia (Crustacea, Branchiopoda) from different geographical origin. Mediterranean populations. J. Plankton Res., 14, 949-960.

HONTORIA, F. AND AMAT, F. 1992b. Morphological characterization of adult Artemia (Crustacea, Branchiopoda) from different geographical origin. American populations. J. Plankton Res., 14, 1461-1471

HUMPHRIES, J. M., BOOKSTEIN, F. L., CHERNOFF, B., SMITH, G. R., ELDER, R. L. AND POSS, S. G. 1981. Multivariate discrimination by shape in relation to size. Syst. Zool., 30, 291-308.

KellogG, v. A. 1906. A new Artemia and its life conditions. Science, 24, 594

LEFCORT, H., ZHANG, L. AND KING, C. E. 1991. Distributions of diploid and pentaploid brine shrimp Artemia parthenogenetica in an illuminated thermal gradient. Can. J. Zool., 69, 2461-2465.

LENZ, P. 1980. Ecology of an alkali-adapted variety of Artemia from Mono Lake, California, USA. In: Persoone, G., Sorgeloos, P., Roels, O. and Jaspers, E. (eds) The Brine Shrimp Artemia, vol. 3: Ecology, Culturing, Use in Aquaculture, pp. 79-96. Universa Press, Wetteren, Belgium.

LENZ, P. AND BRowne, R. A. 1991. Ecology of Artemia. In: Browne, R. A., Sorgeloos, P. and Trotman, C. N. A. (eds) Artemia Biology, pp. 237-254. CRC Press, Boca Raton, FL.

NEI, M. 1972. Genetic distance between populations. Am. Nat., 106, 283-292.
NEI, M. 1978. Estimation of average heterozygosity and genetic distance from a small number of individuals. Genetics, 89, 583-590.

NORUŠIs, M. 1990a. SPSS User's Guide. SPSS Inc., Chicago, USA.

NORUŠIS, M. 1990b. SPSS Advanced Statistics User's Guide. SPSS Inc., Chicago, USA.

NORUŠI, M. 1992a. SPSS for Windows. Base System User's Guide. Release 5. SPSS Inc., Chicago, USA.

NORUŠIs, M. 1992b. SPSS for Windows. Professional Statistics. Release 5. SPSS Inc., Chicago, USA.

o'connell, M. D. 1993. Population Genetics of Atlantic Salmon in Wales. Ph.D. Thesis, University College of Swansea, U.K.

PICCINELli, M. AND PRosdocimi, T. 1968. Descrizione tassonomica delle due specie Artemia salina L. e Artemia persimilis N. Sp. Inst. Lomb. (Rend. Sci.) B, 102, 113-118.

PILlA, E. J. S. 1992. Genetic Differentiation and Speciation in Old World Artemia. Ph.D. Thesis, University College of Swansea.

SHAW, C. R. AND PRASAD, R. 1970. Starch gel electrophoresis of enzymes - a compilation of recipes. Biochem. Genet., 4, 297-320.

SORGELOOS, P., LAVENS, P., LEGER, P., TACKAERT, W. AND VERSICHELE, D. 1986. Manual for the Culture and Use of Brine Shrimp Artemia in Aquaculture. State University of Ghent Press, Ghent, Belgium.

SWOFFORD, D. L. AND SELANDER, R. B. 1981. Biosys-1: a Fortran program for the comprehensive analysis of electrophoretic data in population genetics and systematics. J. Hered., 72, 283.

TATSUOKA, M. M. 1971. Multivariate Analyses. John Wiley and Sons, New York.

VANHAECKE, P., TACKAERT, W. AND SORGELOOS, P. 1987. The biogeography of Artemia: an updated review. In: Sorgeloos, P., Bengtson, D. A., Decleir, W. and Jaspers, E. (eds) Artemia Research and its Applications, vol. 1. Morphology, Genetics, Strain Characterization, Toxicology, pp. 129-155. Universa Press, Wetteren, Belgium.

VERRIL, A. E. 1869. Observations on phyllopod Crustacea of the family Branchipodidae, with description of some new genera and species from America. Proc. Am. Assoc. Adv. Sci., 18, 230-247.

WAPLES, R. S. 1987. A multispecies approach to the analysis of gene flow in marine shore fishes. Evolution, 41, 385-400.

WARD, R. D., SKIBINSKI, D. O. F. AND WoODWARK, M. 1992. Protein heterozygosity, protein structure, and taxonomic differentiation. Evol. Biol., 26, 73-159.

WRIGHT, s. 1978. Evolution and the Genetics of Populations, vol. 4. Variability Within and Among Natural Populations. University of Chicago Press, Chicago.

ZHANG, L. AND LEFCORT, H. 1991. The effects of ploidy level on the thermal distributions of brine shrimp Artemia parthenogenetica and its ecological implications. Heredity, 66, 445-452. 